\title{
Differential DNA methylation analysis across the promoter regions using methylated DNA immunoprecipitation sequencing profiling of porcine loin muscle
}

\author{
Kaj Chokeshaiusaha1 ${ }^{1}$, Denis Puthier ${ }^{2} \mathbb{D}$, Thanida Sananmuang1(iD), Em-on Olanratmanee ${ }^{1}$, Catherine Nguyen $^{2}(\mathbb{D})$ and \\ Roongtham Kedkovid 3 ,4
}

1. Department of Veterinary Science, Faculty of Veterinary Medicine, Rajamangala University of Technology Tawan-OK, Chon Buri, Thailand; 2. Aix-Marseille University, INSERM UMR 1090, TAGC, Marseille, France; 3. Department of Veterinary Medicine, Faculty of Veterinary Science, Chulalongkorn University, Bangkok, Thailand; 4. Swine Reproduction Research Unit, Chulalongkorn University, Bangkok, Thailand.

Corresponding author: Roongtham Kedkovid, e-mail: roongthamk@gmail.com

Co-authors: KC: kaj.chk@gmail.com, DP: denis.puthier@univ-amu.fr, TS: tsananmuang@gmail.com, EO: em-on_ol@rmutto.ac.th, CN: catherine.nguyen@univ-amu.fr

Received: 13-01-2020, Accepted: 05-05-2020, Published online: 16-06-2020

doi: www.doi.org/10.14202/vetworld.2020.1113-1125 How to cite this article: Chokeshaiusaha K, Puthier D, Sananmuang T, Olanratmanee E, Nguyen C, Kedkovid R (2020) Differential DNA methylation analysis across the promoter regions using methylated DNA immunoprecipitation sequencing profiling of porcine loin muscle, Veterinary World, 13(6): 1113-1125.

\begin{abstract}
Background and Aim: Pork leanness and marbling are among the essential traits of consumer preference. To acquire knowledge about universal epigenetic regulations for improving breed selection, a meta-analysis of methylated DNA immunoprecipitation sequencing (MeDIP-seq) profiling data of mixed loin muscle types was performed in this study.

Materials and Methods: MeDIP-seq profiling datasets of longissimus dorsi muscle and psoas major muscles from male and female pigs of Landrace and Tibetan breeds were preprocessed and aligned to the porcine genome. Analysis of differential methylated DNA regions (DMRs) between the breeds was performed by focusing on transcription start sites (TSSs) of known genes ( $-20,000-3000$ bases from TSS). All associated genes were further reviewed for their functions and predicted for transcription factors (TF) possibly associated with their TSSs.
\end{abstract}

Results: When the methylation levels of DMRs in TSS regions of Landrace breed were compared to those of Tibetan breed, 10 DMRs were hypomethylated (Landrace < Tibetan), and 19 DMRs were hypermethylated (Landrace > Tibetan), accordingly $(\mathrm{p} \leq 0.001)$. According to the reviews about gene functions, all associated genes were pieces of evidence for their roles in a variety of muscle and lipid metabolisms. Prediction of the binding TFs revealed the six most abundant binding TFs to such DMRs-associated TSS ( $\leq \leq 0.0001)$ as follows: ZNF384, Foxd3, IRF1, KLF9, EWSR1-FLI1, HES5, and TFAP2A.

Conclusion: Common DMRs-associated TSS between the lean-type and the marbled-type loin muscles were identified in this study. Interestingly, the genes associated with such regions were strongly evidenced for their possible roles on the muscle trait characteristics by which further novel research topics could be focused on them in the future.

Keywords: differential DNA methylation, lean, loin muscle, marbled, methylated DNA immunoprecipitation sequencing, transcription start site.

\section{Introduction}

Pork has been accounted for a large-scale world's meat consumption. Lately, the evolved preference of pork consumers significantly affects its amendment in taste, flavor, juiciness, and tenderness [1,2]. These issues thus become one of the most critical concerns in fields of both veterinary and animal health science as pork leanness and marbling are two essential traits contributing to its quality [1-3]. Diverse cascading gene transcription control by epigenetic modification was well-recognized for its involvement in such phenotypic variations among pig breeds [4-7]. The

Copyright: Chokeshaiusaha, et al. Open Access. This article is distributed under the terms of the Creative Commons Attribution 4.0 International License (http://creativecommons.org/licenses/ by/4.0/), which permits unrestricted use, distribution, and reproduction in any medium, provided you give appropriate credit to the original author(s) and the source, provide a link to the Creative Commons license, and indicate if changes were made. The Creative Commons Public Domain Dedication waiver (http:// creativecommons.org/publicdomain/zero/1.0/) applies to the data made available in this article, unless otherwise stated. knowledge in epigenome concerning porcine musculogenesis and lipogenesis has thus significantly contributed to advance in swine breeding for decades [3-6,8]. For further explanation, epigenetic gene regulation by DNA methylation involves primarily cis-acting DNA elements which are the non-coding DNA binding sites for the gene transcription factors (TFs). Apart from the promoter region, which commonly locates near the transcription start site (TSS), the chromatin loop formation also allows the long-distant cis-acting elements such as enhancers and repressors to cooperate in regulation [9]. Cis-acting elements in mammals, including pigs, usually contain repeated $\mathrm{CpG}$ bases, by which their methylation can interfere TF binding. The methylation patterns are inheritable among animal breeds, including swine, and responsible for different transcription patterns among the tissues of interest $[4-6,9,10]$. To study the intricate regulation patterns of genome-wide DNA methylome, large-scale identification of enriched methylated sequences is thus 
required. Isolation of these methylated DNA fragments could be archived by the antibody against 5-methyl-cytosine, the purification technique recognized as methylated DNA immunoprecipitation (MeDIP) [11]. Coupling of MeDIP and short-read sequencing technologies even allow the high-throughput sequencing of methylated DNA fragments, the technology recognized as MeDIP-sequencing (MeDIP-seq) [12]. Despite its recent introduction, MeDIP-seq has been applied with a few cell types to discover differential DNA methylation patterns among different swine breeds $[4,5,7,11,13]$. Despite the insight into the epigenetic background of swine breeds implied by the past studies, some limitations in such knowledge's application should also be concerned about.

DNA methylation profiling data of a tissue sample are a composited methylation pattern acquired from common cell types in the particular tissue [14]. Methylation profiling of each tissue type should not be considered as a good representative among one another $[14,15]$. Fortunately, differential DNA methylation analysis between lean-type and obese-type pig breeds was previously performed using the MeDIP-seq technology. With few replicated muscle tissue samples, a pooled library of one muscle type was constructed entirely for both DNA-seq and mRNA-seq analyses [4]. In the analysis of sequencing data, numbers of discrete biological replicate crucially influence representativeness of the differential analysis outcome $[16,17]$. By mean of this, the inclusion of numbers of different muscle type biosamples in differential methylation analysis should result in different significant patterns which are universal among various muscle-type tissues.

It should be noted that distances of cis-acting DNA elements from their corresponding TSSs could vary from few to further than $20 \mathrm{~Kb}[9,18]$. While methylated elements are commonly presumed to regulate the transcription of the nearest gene promoter, their distant functions were also evidenced $[19,20]$. With clusters of different TFs possibly associated with these elements, they can complexly control the transcription of the targeted genes $[19,20]$. Virtualization of the methylated elements' distances from the TSS and their associated TFs' prediction is thus crucial for productive genome-wide DNA methylation profiling observation. Despite such feasibility, procedures to attain such knowledge in porcine muscle MeDIP-seq study were still limitedly demonstrated.

Gradual increase of porcine meat muscle MeDIP-seq profiling data in the public database has offered us an opportunity to demonstrate the analytical process with them. With available datasets acquired from two types of joint meat muscles, differential DNA methylation profiling analysis between lean and marbled meat pig breeds was performed in this study. Distance determination and TF prediction respectable to the regions were also demonstrated. By including numbers of different muscle tissue datasets, methylated DNA regions associated with the several well-recognized genes between lean and marbled meat muscle were successfully identified.

\section{Materials and Methods}

\section{Ethical approval}

All datasets used in this study were available in NCBI SRA public site, and no ethical approval was required.

\section{Sample datasets}

The list of porcine meat muscle tissue MeDIP-seq profiling datasets is provided in Table-1. Longissimus dorsi muscle and psoas major muscles from both male and female pigs were included in this study. These muscle tissues were generated from two swine breeds: Landrace as the lean-type breed and Tibetan as the marbled-type meat breed.

\section{Study period and location}

The research was conducted at Department of Veterinary Science, Faculty of Veterinary Medicine, Rajamangala University of Technology Tawan-OK, Chon Buri, Thailand, from August 2019 until the end of January 2020.

\section{Analytical workflow}

The analytical workflow of this study is shown in Figure-1. The preprocessed sample datasets were

Table-1: Porcine muscle tissue datasets used in this study.

\begin{tabular}{|c|c|c|c|}
\hline Dataset & Breed & Sex & Muscle tissue \\
\hline SRR307959 & Landrace & Male & $\begin{array}{l}\text { Longissimus dorsi } \\
\text { muscle }\end{array}$ \\
\hline SRR307960 & Landrace & Male & $\begin{array}{l}\text { Longissimus dorsi } \\
\text { muscle }\end{array}$ \\
\hline SRR307961 & Landrace & Male & $\begin{array}{l}\text { Longissimus dorsi } \\
\text { muscle }\end{array}$ \\
\hline SRR307962 & Landrace & Male & Psoas major muscle \\
\hline 07963 & Landrace & ale & Psoas major muscle \\
\hline SRR307964 & Landrace & Male & uscle \\
\hline SRR307989 & Landrace & Female & $\begin{array}{l}\text { Longissimus dorsi } \\
\text { muscle }\end{array}$ \\
\hline SRR307990 & Landrace & Female & $\begin{array}{l}\text { Longissimus dorsi } \\
\text { muscle }\end{array}$ \\
\hline SRR307991 & Landrace & Female & $\begin{array}{l}\text { Longissimus dorsi } \\
\text { muscle }\end{array}$ \\
\hline SRR307992 & Landrace & Female & Psoas major muscle \\
\hline SRR307993 & Landrace & Fen & or muscle \\
\hline SRR307994 & Landrace & Female & Psoas major muscle \\
\hline SRR308019 & Tibetan & Male & $\begin{array}{l}\text { Longissimus dorsi } \\
\text { muscle }\end{array}$ \\
\hline SRR308020 & Tibetan & Male & $\begin{array}{l}\text { Longissimus dorsi } \\
\text { muscle }\end{array}$ \\
\hline SRR308021 & Tibetan & Male & $\begin{array}{l}\text { Longissimus dorsi } \\
\text { muscle }\end{array}$ \\
\hline 22 & Tib & $\mathrm{Mal}$ & Psoas major muscl \\
\hline & Tibe & Male & or muscle \\
\hline SRR308024 & Tibetan & Male & Psoas major muscle \\
\hline SRR308049 & Tibetan & Female & $\begin{array}{l}\text { Longissimus dorsi } \\
\text { muscle }\end{array}$ \\
\hline SRR308050 & Tibetan & Female & $\begin{array}{l}\text { Longissimus dorsi } \\
\text { muscle }\end{array}$ \\
\hline SRR308051 & Tibetan & Female & $\begin{array}{l}\text { Longissimus dorsi } \\
\text { muscle }\end{array}$ \\
\hline SRR308052 & Tibetan & Fem & Psoas major muscle \\
\hline SRR308053 & Tibetan & Fem & Psoas major muscle \\
\hline SRR308054 & Tibetan & Female & Psoas major muscle \\
\hline
\end{tabular}




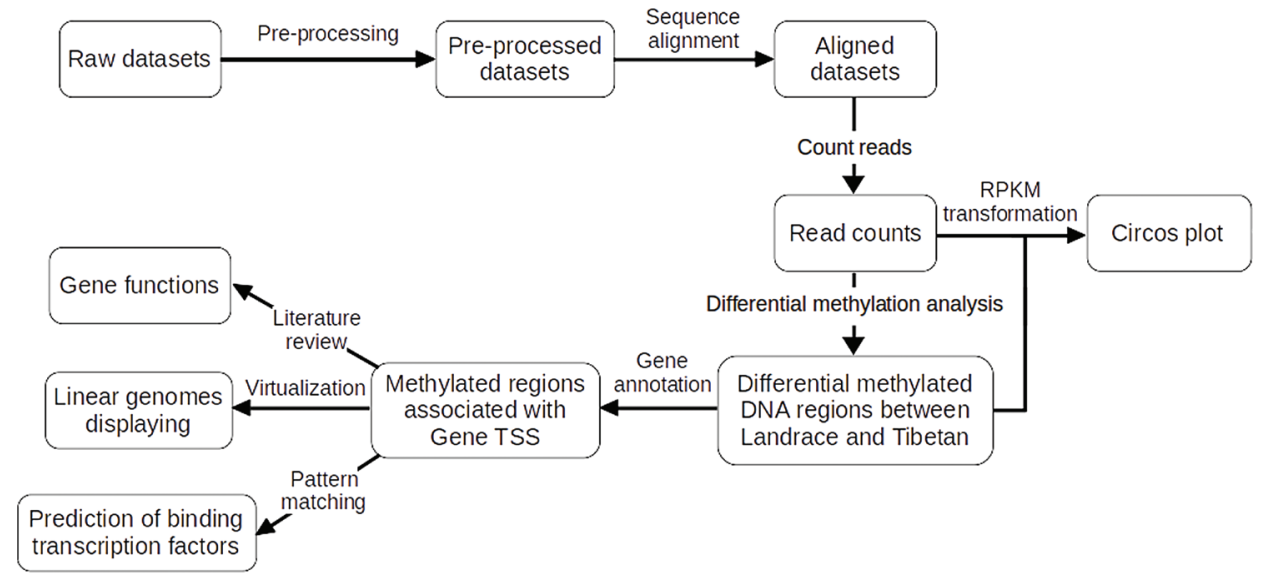

Figure-1: Analytical workflow for this study.

aligned to the porcine genome to acquire aligned datasets and counted for the methylated DNA sequence reads (read counts). Differential DNA methylation analysis between muscle datasets of Landrace and Tibetan pigs was performed. Both differential methylation results and read counts in Reads Per Kilobase Millions were visualized by the Circos plot (Figure-1). Differentially methylated DNA regions (DMRs) between Landrace and Tibetan pigs were subsequently determined for their proximity to TSSs of the associated genes $(-20,000-3000$ bases from TSS) and displayed by a customized plot (linear genomes displaying in Figure-1). All the associated genes were reviewed for their functions. Finally, TFs associated with these regions would then be predicted (Figure-1).

\section{Data preprocessing and quality assessment}

The sequence read archive (SRA) files of porcine muscle MeDIP-Seq datasets were obtained from the SRA database (https://www.ncbi.nlm.nih.gov/sra) (Table-1). Data preprocessing was performed as previously described with some modifications [21]. Briefly, each dataset was aligned to the porcine reference genome (Sus scrofa UCSC susScr3) with the Bowtie2 aligner (version 2.3.4.3) [22]. Duplicated sequences of the aligned datasets were then removed [23]. Phred quality score was determined by FastQC [24]. The assessment of MeDIP-Seq quality and DNA methylation score was performed by Bioconductor package MEDIPS (250-bp windows) after extending read to a length of $300 \mathrm{bp}$ [25].

\section{DMRs between landrace and Tibetan pigs}

DMRs between Landrace and Tibetan pigs were identified $(p \leq 0.001)$ by edgeR (exact test for negative binomial distribution) integrated with the MEDIPS package. TSSs of porcine genes were annotated using the porcine genome (Sscrofa 11.1) acquired from the Ensembl database (version 95) (https://asia.ensembl. org/info/data/ftp/index.html). This study only considered the DMRs within $-20,000-+3000$ bases from TSS. Gene promoter region was considered from -1000 to +500 bases from TSS and was exclusively remarked for the presence of differential methylation within the regions in the karyoplot (Figure-2).

\section{Prediction of binding TFs}

RSAT Matrix-Scan (http://rsat.ulb.ac.be/) was used to detect TF binding sites (http://rsat.sb-roscoff. $\mathrm{fr} /$ ) among the DMRs. Individual sites were predicted using the various position matrix of non-redundant TF binding profiles of vertebrates (JASPAR CORE, non-redundant vertebrates database) and filtered using a threshold on $\mathrm{p}=10^{-6}$. For matrix-scan, the first-order Markov chain background model was calculated from the input sequence set.

\section{Virtualization}

Count reads of overall methylated DNA regions along with their DMRs between Landrace and Tibetan pigs were illustrated by the Circos plot using the Bioconductor OmicCircos package [26]. To display the DMRs associated with the target genes of interest, the karyoploteR package [27]. was utilized to draw the plot for displaying the locations of DMRs and their associated TSSs.

\section{Results}

Genome-wide DNA methylation profiling and their differentially methylated DNA regions

After removing the contaminated, low quality, and adapter sequences, each preprocessed dataset had approximately 64 million clean reads (40-42 bps) with at least an $85 \%$ alignment rate to the $S$. scrofa reference genome. The data showed sufficient sequence depth, and coverage analyses revealed that approximately $95 \%$ of all CpGs in the S. scrofa genome was covered at least one-fold, whereas nearly $50 \%$ of CpGs were covered more than five-fold. Patterns of canonical epigenetic DNA methylation observed among longissimus dorsi muscle and psoas major muscle tissues acquired from both Landrace and Tibetan breeds were similar, by which strong positive correlation across the breed was demonstrated by correlation analysis $\left(\mathrm{r}=0.75-0.95, \mathrm{p}<10^{-16}\right)$. The comparison of the DNA methylation profiles of the Landrace and Tibetan breeds revealed 74,009 DMRs $(\mathrm{p} \leq 0.001)$ 

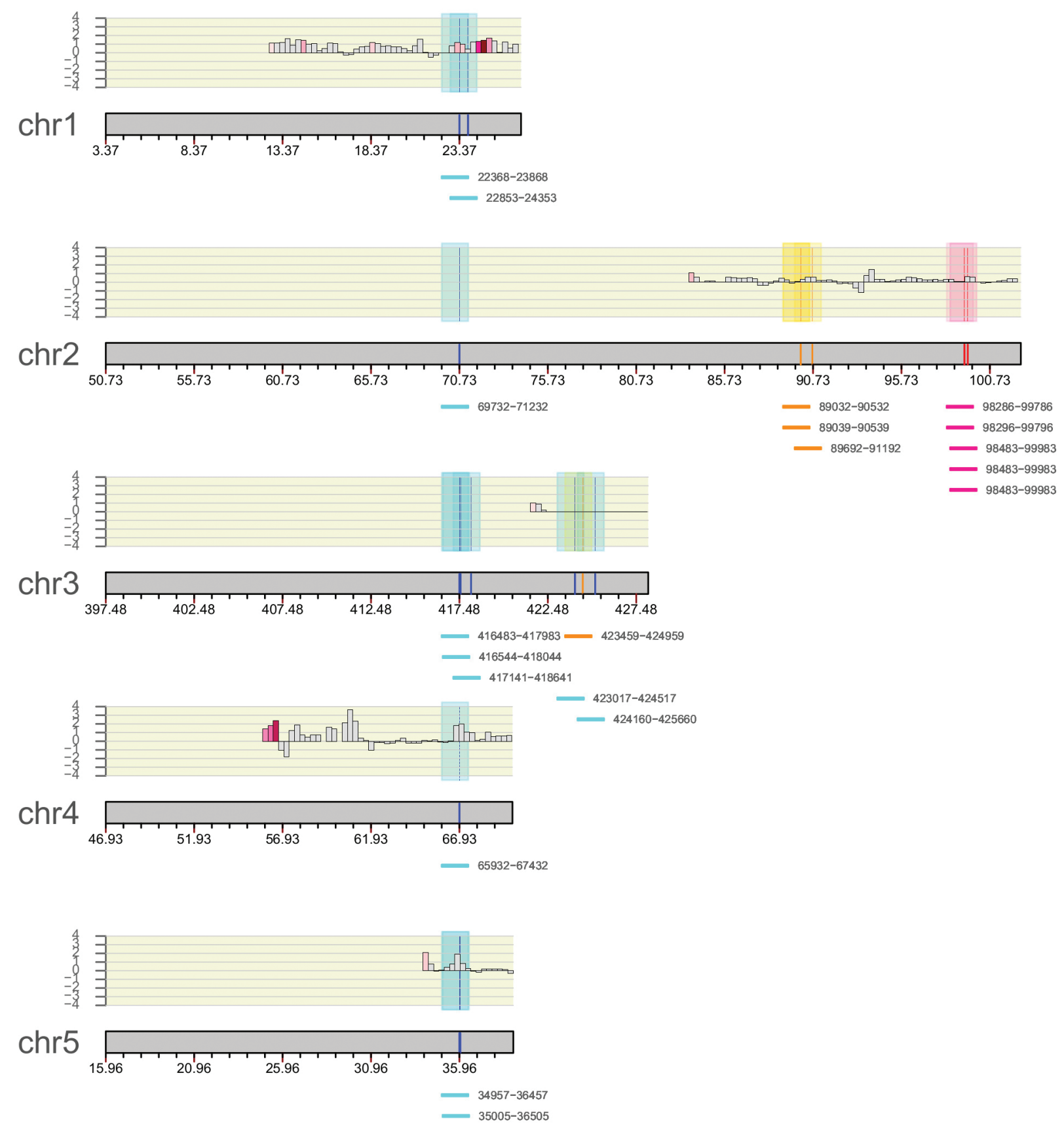

a

\begin{tabular}{ccclrrr}
\hline Chr & \multicolumn{1}{c}{ GenelD } & Color & GeneName & Start & \multicolumn{1}{l}{ End } & log2FC \\
\hline chr1 & ENSSSCG00000027257 & & PSMB1 & 12601 & 12900 & 1.14 \\
& & & & 14401 & 14700 & 1.46 \\
& & & & 18301 & 18600 & 1.20 \\
& & & 23101 & 23700 & 1.09 \\
& & & 24301 & 25200 & 1.47 \\
\hline chr2 & ENSSSCG00000014560 & & COX8H & 83701 & 84000 & 1.08 \\
\cline { 2 - 7 } & ENSSSCG00000014561 & NLRP6 & 83701 & 84000 & 1.08 \\
\cline { 2 - 7 } & ENSSSCG00000025023 & & PGGHG & 83701 & 84000 & 1.08 \\
\hline chr3 & ENSSSCG00000007542 & & PRKAR1B & 421501 & 421800 & 1.04 \\
\cline { 2 - 7 } & ENSSSCG00000007543 & & DNAAF5 & 421501 & 421800 & 1.04 \\
\hline chr4 & ENSSSCG00000038957 & & 55801 & 56700 & 1.87 \\
\hline chr5 & ENSSSCG00000021265 & & ACR & 33901 & 34200 & 2.10 \\
\hline
\end{tabular}

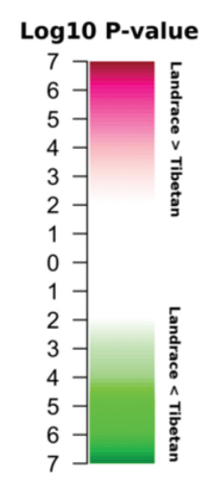

Figure-2: Linear genomes displaying methylated regions associated with gene transcription start sites (TSS). The karyoplot of 18 porcine genes with the presence of methylated DNA regions associated with their TSS $(-20,000-3000)$ and promoter regions (-1000-500). Partial porcine genome sequences acquired from 17 chromosomes (chr) containing all associated gene transcripts were drawn with loci index (a-d). Promoter regions of transcripts presented on the same chromosome were demonstrated in different shaded colors - sky blue, orange, and pink, accordingly. Differentially hypomethylated to hypermethylated regions were demonstrated by gradient colors from deep blue to deep red respective to their - $\log _{10}$ p-values. The levels of differences were indexed by two-fold changes ( - for hypomethylated and + for hypermethylated). The bottom legends indicated the Ensembl ID and common names of the targeted genes in each of the chr. 

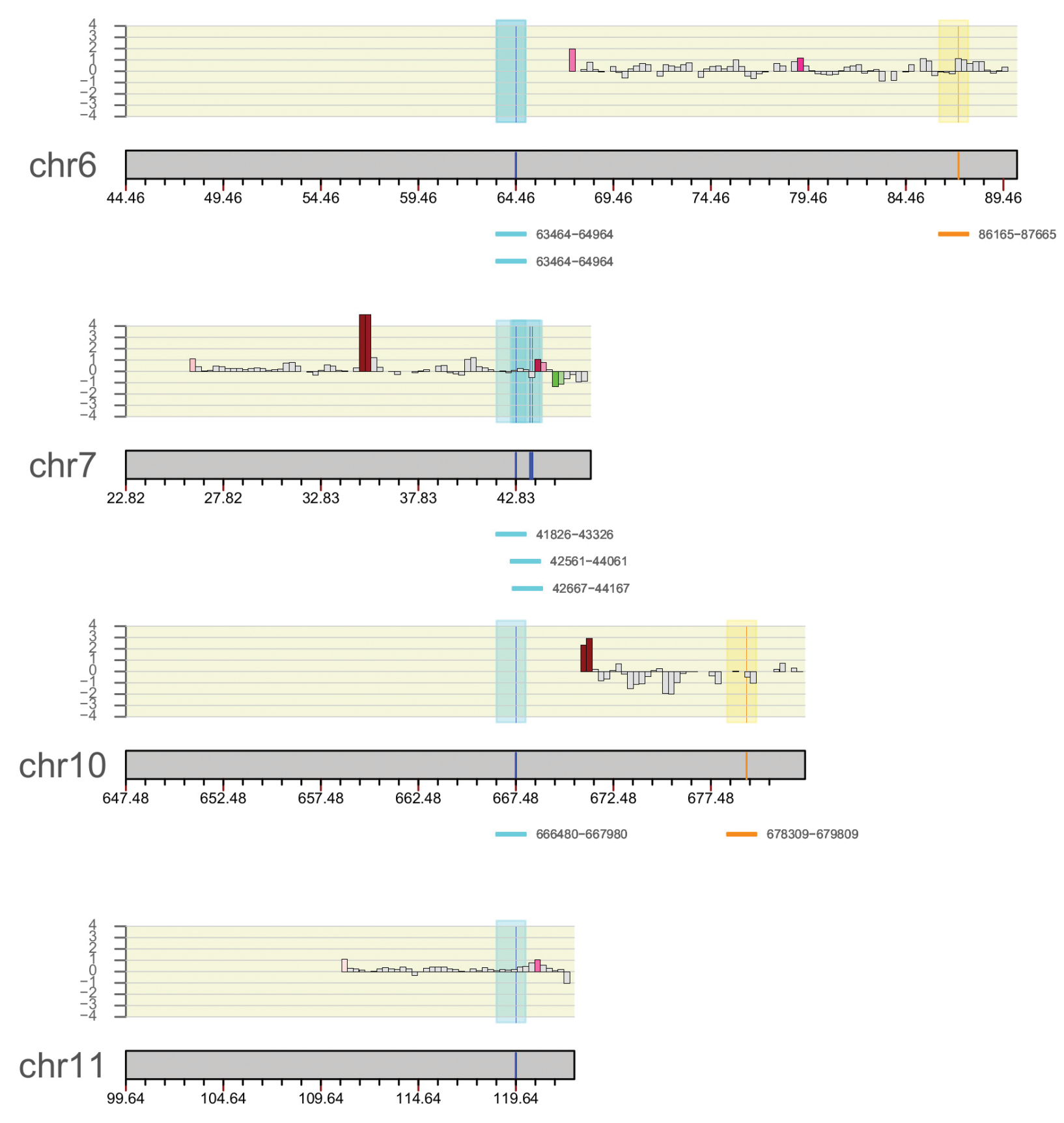

118642-120142

\begin{tabular}{|c|c|c|c|c|c|c|}
\hline Chr & GenelD & Color & GeneName & Start & End & $\log 2 \mathrm{FC}$ \\
\hline \multirow[t]{4}{*}{ chr6 } & ENSSSCG00000026662 & & hPRDM7 & 67201 & 67500 & 1.95 \\
\hline & & & & 78901 & 79200 & 1.18 \\
\hline & ENSSSCG00000029761 & & hURAD & 67201 & 67500 & 1.95 \\
\hline & & & & 78901 & 79200 & 1.18 \\
\hline \multirow[t]{4}{*}{ chr7 } & ENSSSCG000C & & DUSP22 & 26101 & 26400 & 1.08 \\
\hline & & & & 34801 & 35400 & 5.64 \\
\hline & & & & 43801 & 44400 & 0.92 \\
\hline & & & & 44701 & 45300 & -1.22 \\
\hline \multirow[t]{2}{*}{ chr10 } & ENSSSCG00000010801 & & $\mathrm{CDC7}$ & 670801 & 671400 & 2.61 \\
\hline & ENSSSCG00000031991 & & GLRX2 & 670801 & 671400 & 2.61 \\
\hline \multirow[t]{2}{*}{ chr11 } & ENSSSCG00000022638 & & ATP12A & 110 & 111000 & 1.09 \\
\hline & & & & 120601 & 120900 & 1.03 \\
\hline
\end{tabular}

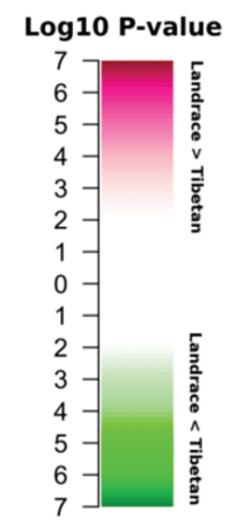

Figure-2: (Continued). 

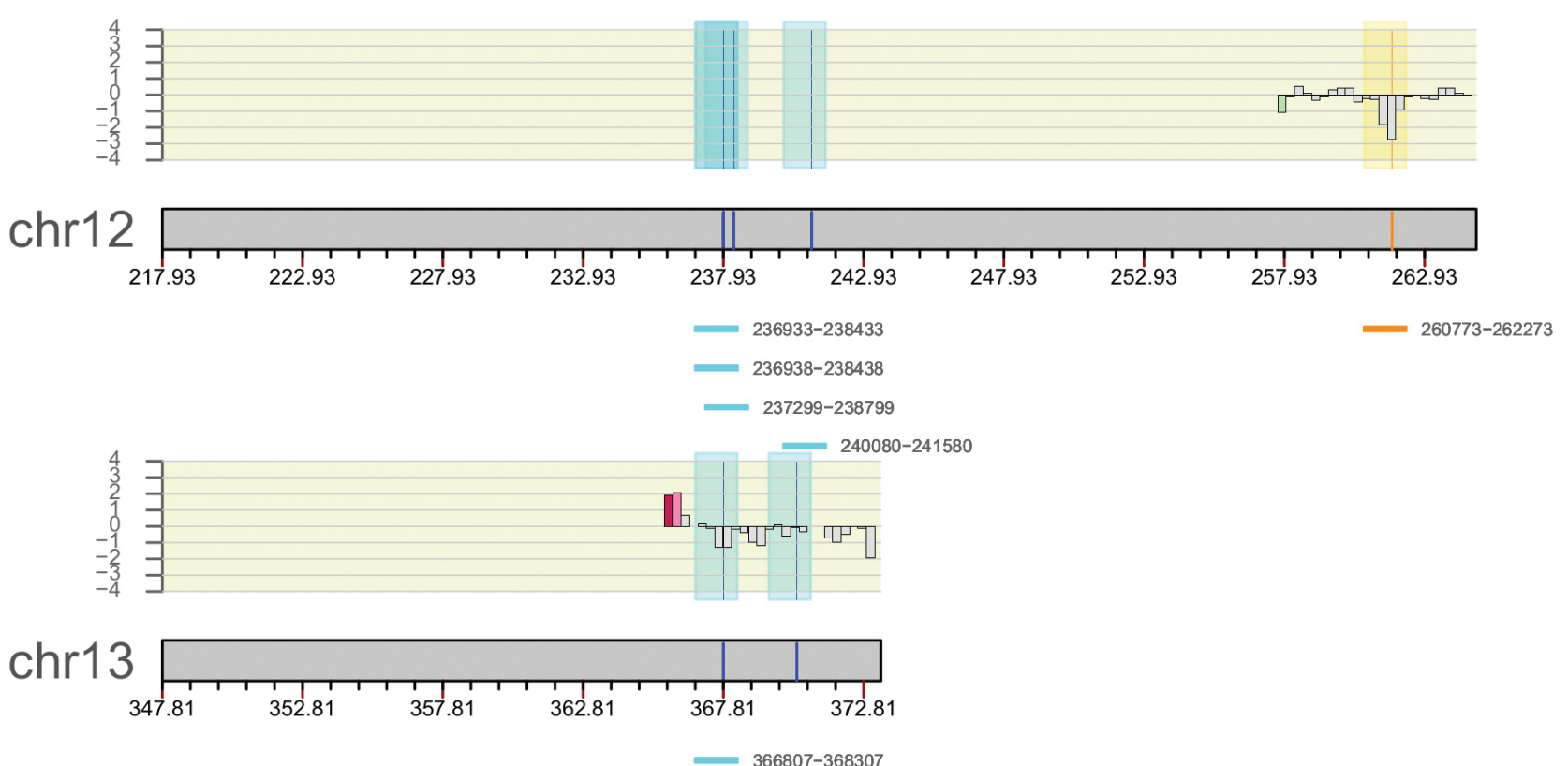

369426-370926
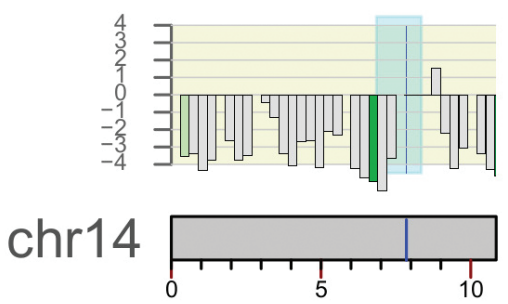

- $6850-8350$

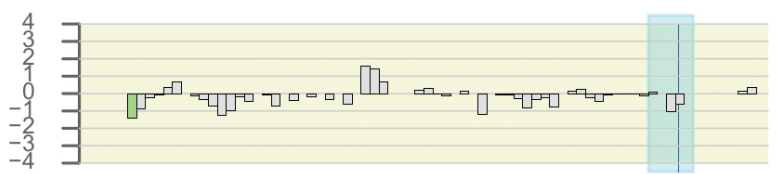

chr15

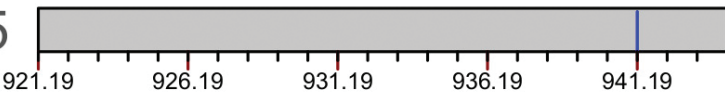

940193-941693

\begin{tabular}{llllrrr}
\hline \multicolumn{1}{c}{ Chr } & \multicolumn{1}{c}{ GenelD } & Color & GeneName & \multicolumn{1}{c}{ Start } & \multicolumn{1}{c}{ End } & log2FC \\
\hline chr12 ENSSSCG00000017137 & & METRNL & 257701 & 258000 & -1.09 \\
\cline { 2 - 6 } & ENSSSCG00000027229 & & & 257701 & 258000 & -1.09 \\
\hline chr13 ENSSSCG00000011178 & & CPNE4 & 365701 & 366300 & 2.01 \\
\hline chr14 ENSSSCG00000038672 & & hCHCHD2 & 301 & 600 & -3.54 \\
& & & 6601 & 6900 & -5.49 \\
\hline chr15 ENSSSCG00000022011 & & NMI & 922801 & 923100 & -1.40 \\
\hline
\end{tabular}

Figure-2: (Continued)

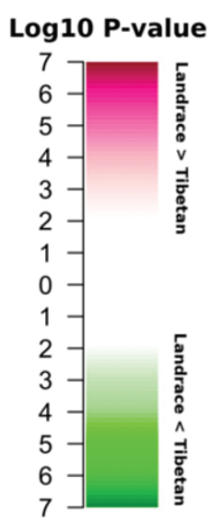



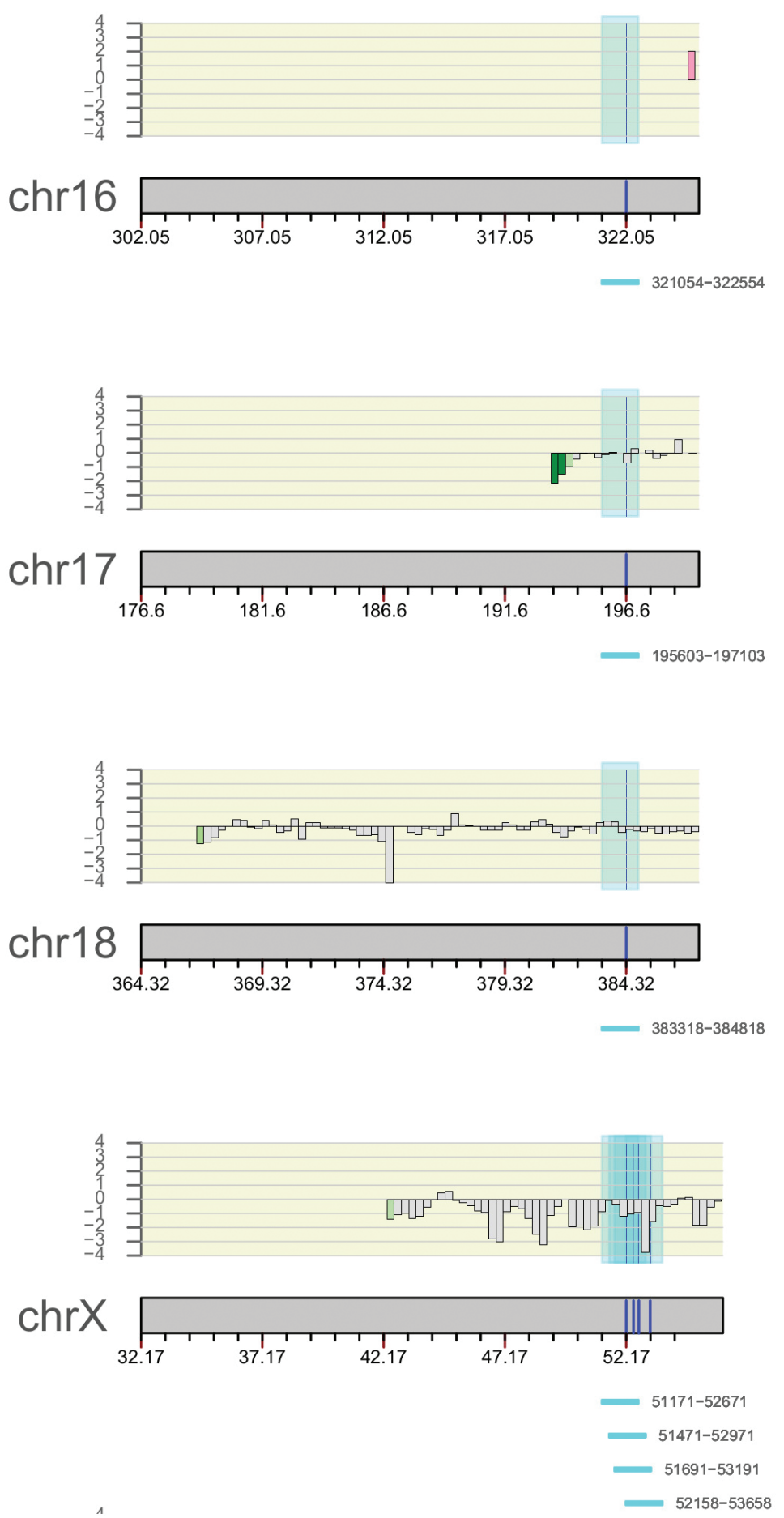

d

\begin{tabular}{|c|c|c|c|c|c|}
\hline GenelD & Color & GeneName & Start & End & $\log 2 F C$ \\
\hline chr16 ENSSSCG00000032942 & & & 324601 & 324900 & 2.00 \\
\hline chr17 ENSSSCG00000020190 & & & 193501 & 194400 & -1.53 \\
\hline chr18 ENSSSCG00000020232 & & RF00026 & 366601 & 366900 & -1.24 \\
\hline chrX ENSSSCG00000038044 & & GYG2 & 42301 & 42600 & -1.42 \\
\hline
\end{tabular}

Figure-2: (Continued). 
after merging significant neighboring windows. When compared, methylation levels of Landrace breed in these DMRs to those of Tibetan breed, 28,028 hypomethylated regions (Landrace $<$ Tibetan) and 45,981 hypermethylated regions (Landrace > Tibetan) were found scattering among somatic and $\mathrm{X}$ chromosomes (Figure-3).

\section{Differentially methylated regions associated with TSS of porcine genes}

The total of 29 DMRs, which were ten hypomethylated and 19 hypermethylated DMRs, was found distributed among the TSS regions $(-20,000-$ +3000 from TSS) of 18 known genes $(\mathrm{p} \leq 0.001)$ (Figure-2a-d). Among these TSS-associated DMRs, seven DMRs consisting of one hypomethylated and six hypermethylated DMRs were presented in the gene promoter areas $(-1000-+500$ from TSS). The hypomethylated promoter region was contributed to the ESSSCG00000038672 gene, which is orthologous to the human CHCHD2 gene ( $h \mathrm{CHCHD} 2)$ (chr15 in Figure-2c), while hypermethylated promoter regions were presented in ESSSCG00000027257 (PSMB1) (chr1 in Figure-2a) and ESSSCG00000031489
(DUSP22) (chr7 in Figure-2b). Two miRNA genes, ENSSSCG00000020190 and ENSSSCG00000020232 (RF00026) were identified (Figure-2d). Interestingly, subsequent gene function review manifested considerable affiliation of several protein-coding genes, except ENSSSCG00000021265 (ACR), with the metabolism and function of muscle tissue (Table-2) [28-59]. The six most abundant TFs predicted to bind the DMRs in these TSS regions $(\mathrm{p} \leq 0.0001)$ were as follows: ZNF384 (56 times), Foxd3 (25 times), IRF1 (24 times), KLF9 (17 times), EWSR1-FLI1 (12 times), HES5 (12 times), and TFAP2A (12 times). For each DMR, the predicted binding TF with the highest significant score is displayed in Table-3.

\section{Discussion}

DNA methylation patterns mutually distributed among the tissue types usually implied universal metabolic features shared in common among them [14]. Based on such an approach, this study included considerable MeDIPS datasets generated from two common loin meat muscle tissues, longissimus dorsi muscle and psoas major, with the

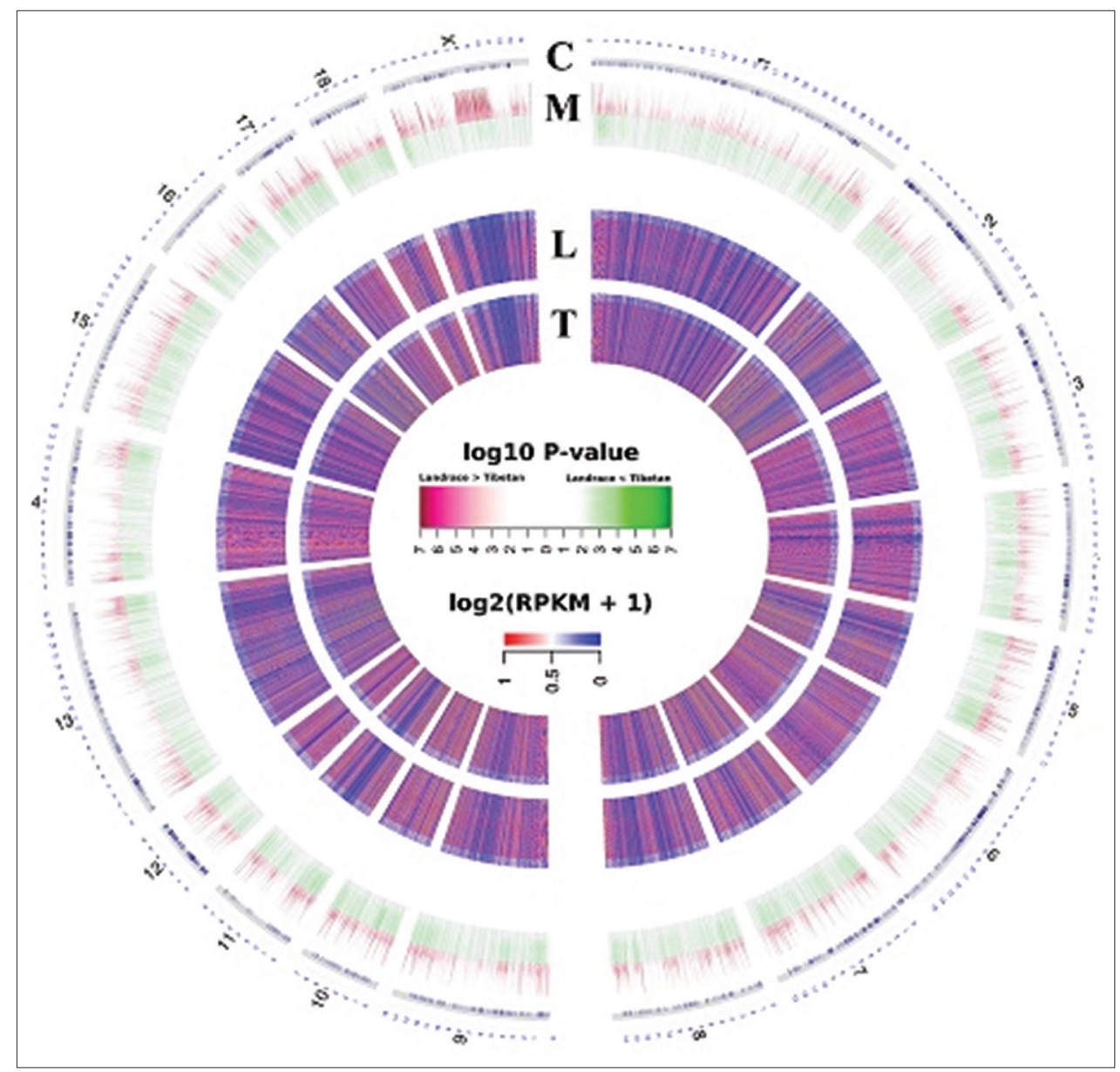

Figure-3: Circos plot of overall methylated DNA regions in the porcine genome. The circos plot demonstrated differentially methylated DNA regions among porcine chromosomes (C panel) (chr1-18 and chrX). Differences in methylation levels between Landrace and Tibetan pigs along each chromosome's regions were manifested (M panel). The legend presented $\log _{10} \mathrm{p}$-values of regions with gradient colors from red (higher methylation levels in Landrace) to green (higher methylation levels in Tibetan), accordingly. $\log _{2}(R P K M+1)$ values of count methylated regions acquired from Landrace $(L$ panel) and Tibetan (T panel) pig breeds were shown. RPKM=Reads per kilobase millions. 
Table-2: Methylated TSS associated genes with evidenced roles in muscle tissues.

\begin{tabular}{|c|c|c|c|c|}
\hline Chr & GeneID & $\begin{array}{l}\text { Common } \\
\text { name }\end{array}$ & Function & References \\
\hline chr1 & ENSSSCG00000027257 & PSMB1 & $\begin{array}{l}\text { Upregulated according to obesity, PSMB1 was } \\
\text { transcriptional activator of RBP4 - a gene associated with } \\
\text { insulin resistance and transcription activation of adipocyte. }\end{array}$ & {$[28,29]$} \\
\hline \multirow[t]{3}{*}{ chr2 } & ENSSSCG00000014560 & $\mathrm{COX} 8 \mathrm{H}$ & $\begin{array}{l}\text { COX8H was related to cytochrome } \mathrm{C} \text { oxidase }- \text { the crucial } \\
\text { enzyme with potential role in oxidative and fatty acid } \\
\text { metabolisms of muscle fibers. }\end{array}$ & {$[30,31]$} \\
\hline & ENSSSCG00000014561 & NLRP6 & $\begin{array}{l}\text { NLRP6 was the sensor component of NLPP3 inflammasome } \\
\text { which could enhance muscular dystrophy and was strongly } \\
\text { associated with obesity. }\end{array}$ & {$[7,32-34]$} \\
\hline & ENSSSCG00000025023 & PGGHG & $\begin{array}{l}\text { PGGHG was a catalyzing enzymes of D-glucose, and thus } \\
\text { could affect both muscle and adipose cell's metabolisms. }\end{array}$ & {$[35,36]$} \\
\hline chr3 & ENSSSCG00000007542 & PRKAR1B & $\begin{array}{l}\text { PRKAR1B encoded a regulatory subunit of cyclic AMP- } \\
\text { dependent protein kinase } A \text { in the signaling pathway of the } \\
\text { second messenger CAMP - contributing to myofiber size } \\
\text { and negatively associating with intramuscular fat. }\end{array}$ & {$[32,37]$} \\
\hline \multirow[t]{2}{*}{ chr6 } & ENSSSCG00000026662 & hPRDM7 & $\begin{array}{l}\text { PRDM7 could function as a histone methyltransferase, and } \\
\text { thus was likely affect DNA methylation affecting muscle } \\
\text { tissue development and function. }\end{array}$ & {$[38]$} \\
\hline & ENSSSCG00000029761 & hURAD & $\begin{array}{l}\text { URAD enzyme catalyzed anti-oxidant process of uric acid to } \\
\text { form allantoin - the marker of oxidative stress in muscle. }\end{array}$ & {$[39,40]$} \\
\hline \multirow[t]{2}{*}{ chr7 } & ENSSSCG00000031489 & DUSP22 & $\begin{array}{l}\text { DUSP22 protein activate the JNK signaling pathway - } \\
\text { regulating the phosphorylation state of several kinases in } \\
\text { skeletal muscle and requiring for obesity. }\end{array}$ & {$[41-44]$} \\
\hline & & & $\begin{array}{l}\text { DUSP } 22 \text { was an obesity candidate gene which was } \\
\text { hypermethylated in obese subject. }\end{array}$ & {$[45-47]$} \\
\hline \multirow[t]{2}{*}{ chr10 } & ENSSSCG00000010801 & CDC73 & $\begin{array}{l}\text { CDC73 protein was a subunit of PAF protein complex } \\
\text { associated with the RNA polymerase II subunit and a } \\
\text { histone methyltransferase complex, and thus played role in } \\
\text { chromatin modifications and gene transcription of muscle } \\
\text { tissue. }\end{array}$ & {$[48]$} \\
\hline & ENSSSCG00000031991 & GLRX2 & $\begin{array}{l}\text { GLRX2 protein implicated MITOCHONDRIAL REDOX } \\
\text { REGULATION preventing oxidative damage and was } \\
\text { evidenced to control oxidative phosphorylation in cardiac } \\
\text { muscles. }\end{array}$ & {$[49,50]$} \\
\hline chr11 & ENSSSCG00000022638 & ATP12A & $\begin{array}{l}\text { ATP12A was responsible for potassium absorption for } \\
\text { muscle contraction - by which the lack of potassium could } \\
\text { result in muscle destruction by decreased blood flow. }\end{array}$ & {$[51,52]$} \\
\hline \multirow[t]{2}{*}{ chr12 } & ENSSSCG00000017137 & METRNL & $\begin{array}{l}\text { METRNL product was associated with adipocyte browning } \\
\text { and glucose tolerance. }\end{array}$ & [53] \\
\hline & ENSSSCG00000027229 & & $\begin{array}{l}\text { Several miRNAs in skeletal muscle could regulate } \\
\text { myogenesis, hypertrophy, atrophy, and regeneration. }\end{array}$ & {$[54]$} \\
\hline chr13 & ENSSSCG00000011178 & CPNE4 & $\begin{array}{l}\text { CPNE4 product was calcium-dependent phospholipid- } \\
\text { binding protein, and thus can involve in several calcium- } \\
\text { mediated processes in muscle tissue. }\end{array}$ & {$[55]$} \\
\hline chr14 & ENSSSCG00000038672 & $\mathrm{hCHCHD} 2$ & $\begin{array}{l}\text { CHCHD2 was a transcription factor of cytochrome } \mathrm{C} \text { oxidase } \\
\text { required for optimal mitochondrial function of muscle cell. }\end{array}$ & {$[56]$} \\
\hline chr15 & ENSSSCG00000022011 & NMI & $\begin{array}{l}\mathrm{N} \text {-myc can functionally replace c-myc in murine } \\
\text { development, cellular growth, and differentiation. }\end{array}$ & {$[57]$} \\
\hline chr16 & ENSSSCG00000032942 & DAP & $\begin{array}{l}\text { DAP was necessary for complete myotube development } \\
\text { during muscle fiber formation. }\end{array}$ & {$[58]$} \\
\hline chrX & ENSSSCG00000038044 & GYG2 & $\begin{array}{l}\text { Glycogenin was important for muscle glycogenesis - by } \\
\text { which glycogen over-accumulation could result in fatigue } \\
\text { reduced function of muscle. }\end{array}$ & [59] \\
\hline
\end{tabular}

differential methylation analysis to discover the universal differences in DNA methylation pattern of loin muscle to understand the differences between lean and marbled meat pig breeds. Since only rigid cellular metabolisms were controlled in universal patterns among tissue types, limited numbers of genes with differentially methylated TSS regions were expected as successfully demonstrated in this study.

Several novel genes with TSS-associated DMRs were also exclusively identified in this study. Apart from constructing sample libraries from different meat tissues, other factors, such as muscle types, dataset numbers, and pig breeds, were also considered as contributors to such achievement (Figure-2). For the available virtualization of these regions' localization following their associated genes, the karyoplot was successfully applied [27]. Among all the presented TSS-associated DMRs, some DMRs in the promoter regions of three coding genes, ESSSCG00000038672 ( $\mathrm{hCH}$ CHD2), ESSSCG00000027257 (PSMB1), and ESSSCG00000031489 (DUSP22) were also 
Table-3: Top predicted transcription factors binding to differentially methylated TSS regions.

\begin{tabular}{|c|c|c|c|c|}
\hline TSS regions & Transcription factor & Weight & p-value & *Significant score \\
\hline chr1:12601-12900 & EGR4 & 8.7 & $1.6 \mathrm{E}-05$ & 4.796 \\
\hline chr1:14401-14700 & ZSCAN4 & 8.3 & $6.3 \mathrm{E}-06$ & 5.201 \\
\hline chr1:18301-18600 & GATA1::TAL1 & 10.1 & $8.1 \mathrm{E}-06$ & 5.092 \\
\hline chr1:23101-23700 & TEAD1 & 9.3 & $2.3 \mathrm{E}-06$ & 5.638 \\
\hline chr1:24301-25200 & ZNF143 & 9.1 & $3.2 \mathrm{E}-06$ & 5.495 \\
\hline chr10:670801-671400 & Foxd3 & 10.3 & $3.5 \mathrm{E}-06$ & 5.456 \\
\hline chr11:110701-111000 & KLF9 & 11.6 & $5.8 \mathrm{E}-07$ & 6.237 \\
\hline chr11:120601-120900 & Dmbx1 & 10.7 & $3.2 \mathrm{E}-06$ & 5.495 \\
\hline chr12:257701-258000 & ZNF384 & 10.2 & $4.8 \mathrm{E}-07$ & 6.319 \\
\hline chr13:365701-366300 & ZNF384 & 10.1 & $1.1 \mathrm{E}-06$ & 5.959 \\
\hline chr14:10801-11100 & NFYA & 9.6 & $1.2 \mathrm{E}-05$ & 4.921 \\
\hline chr14:26401-26700 & SPI1 & 4.7 & $2.9 \mathrm{E}-05$ & 4.538 \\
\hline chr14:301-600 & CTCF & 14.2 & 6.7E-08 & 7.174 \\
\hline chr14:6601-6900 & Foxd3 & 11 & $9.1 \mathrm{E}-07$ & 6.041 \\
\hline chr15:922801-923100 & TBP & 10.7 & $1.5 \mathrm{E}-06$ & 5.824 \\
\hline chr16:324601-324900 & RBPJ & 9.2 & $1 \mathrm{E}-05$ & 5 \\
\hline chr17:193501-194400 & NFIL3 & 10 & $8.4 \mathrm{E}-06$ & 5.076 \\
\hline chr18:366601-366900 & EWSR1-FLI1 & 6.8 & $1.3 \mathrm{E}-06$ & 5.886 \\
\hline chr2:83701-84000 & RELB & 8.9 & $2 \mathrm{E}-05$ & 4.699 \\
\hline chr3:421501-421800 & SNAI2 & 8.7 & $1.7 \mathrm{E}-06$ & 5.77 \\
\hline chr4:55801-56700 & HSF4 & 11.4 & $1.4 \mathrm{E}-06$ & 5.854 \\
\hline chr5:33901-34200 & $\mathrm{HIC2}$ & 8.4 & $1.1 \mathrm{E}-05$ & 4.959 \\
\hline chr6:67201-67500 & Dlx2 & 8.3 & $7.5 \mathrm{E}-06$ & 5.125 \\
\hline chr6:78901-79200 & Arid5a & 10.1 & $3.1 \mathrm{E}-06$ & 5.509 \\
\hline chr7:26101-26400 & SP2 & 12.4 & $4.2 \mathrm{E}-07$ & 6.377 \\
\hline chr7:34801-35400 & Stat5a::Stat5b & 9.9 & 5.7E-06 & 5.244 \\
\hline chr7:43801-44400 & HIF1A & 11.8 & $1.6 \mathrm{E}-07$ & 6.796 \\
\hline chr7:44701-45300 & KLF5 & 11.2 & 8.7E-07 & 6.06 \\
\hline chrX:42301-42600 & KIf1 & 11.1 & $1.7 \mathrm{E}-06$ & 5.77 \\
\hline
\end{tabular}

*Significant score $=-\log 10$ ( $p$-value $\times$ nb.words). TSS=Transcription start sites

noticeable (Figure-2a-c). Due to the robust influence of promoter on epigenetic gene regulation $[9,19]$. these differentially methylated genes should be considered as exclusive candidates for further transcription determination. Of note, the current study only focused on TSS-associated methylated regions. Further analysis of other potential epigenetic gene regulation regions, including gene exons [60] and introns $[61,62]$, was thus encouraged in separated studies.

In this study, several novel genes in loin muscles manifested their differences in the TSS region methylation levels in Landrace comparing to Tibetan pigs. Landrace pig is recognized for its lean large muscle bundle, while Tibetan pig muscle is more compact with outstanding marbling levels [63]. The different characteristics of the two breeds thus greatly denoted the diverge metabolisms of their muscle tissues. Supporting this, almost all differentially methylated genes also manifested their evidenced functions relating to musculogenesis and lipid metabolisms in this study (Table-2). Interestingly, two differentially methylated miRNA genes, ENSSSCG00000020190 and ENSSSCG00000020232, were also identified (Figure-2d), contributing new targets for a miRNA study in the skeletal muscles [54].

The regulatory function of the acquired TSSassociated DMRs required further biological evaluation despite the knowledge of their methylation levels. Since DNA methylation could either inhibit or recruit particular TFs in various circumstances $[9,20,64]$. the prediction of candidate TFs binding regions was thus crucial to study their epigenetic gene regulation. Due to the limited demonstration of such process in porcine skeletal muscle MeDIP-seq study, we introduced the RSAT Matrix-Scan as a convenient web-based tool for the prediction of TF binding. Of note, this study intentionally showed only TFs with the highest prediction significant score for demonstration. Since each TSS region could be occupied by various TFs [65]. other significantly predicted TFs $\left(\mathrm{p} \leq 10^{-6}\right)$ should also be considered for any further intensive study.

\section{Conclusion}

In summary, the determination of TSS regions that were differentially methylated between lean-type 
and marbled-type pig breeds in loin meat muscle tissues was demonstrated as a novel approach in this study. The procedure rendered the limited numbers of differentially methylated genes, but with strong concatenation with the different muscle characteristics presented between these two breeds. We also introduced a karyoplot for the available virtualization of TSS-associated DMRs along with their candidate TFs binding to them. As a result, the knowledge acquired from this study established several new research topics in lean and marbled meats to evaluate the epigenetic gene regulation. It is worth noting that this study aimed to demonstrate a beneficial strategy for porcine muscle MeDIP-Seq data analysis, which was also applicable to other biological systems.

\section{Authors' Contributions}

$\mathrm{KC}$, TS and RK planned the study design, collected the datasets, and analyzed the data. EO and $\mathrm{CN}$ refined the study design and the objective. DP carried out technical coding correction and hardware maintenance. $\mathrm{KC}$ and $\mathrm{RK}$ drafted and reviewed the manuscript. All authors read and approved the final manuscript.

\section{Acknowledgments}

The authors are thankful to the Office of Academic Resource and Information Technology, Rajamangala University of Technology Tawan-OK for the contribution of server computer for the burden analysis. The authors did not receive any funds for this study.

\section{Competing Interests}

The authors declare that they have no competing interests.

\section{Publisher's Note}

Veterinary World remains neutral with regard to jurisdictional claims in published institutional affiliation.

\section{References}

1. Madeira, M.S., Costa, P., Alfaia, C.M., Lopes, P.A., Bessa, R.J.B., Lemos, J.P.C. and Prates, J.A.M. (2013) The increased intramuscular fat promoted by dietary lysine restriction in lean but not in fatty pig genotypes improves pork sensory attributes. J. Anim. Sci., 91(7): 3177-3187.

2. Moeller, S.J., Miller, R.K., Edwards, K.K., Zerby, H.N., Logan, K.E., Aldredge, T.L., Stahl, C.A., Boggess, M. and Box-Steffensmeier, J.M. (2010) Consumer perceptions of pork eating quality as affected by pork quality attributes and end-point cooked temperature. Meat Sci., 84(1): 14-22.

3. Cheng, W., Cheng, J.H., Sun, D.W. and Pu, H. (2015) Marbling analysis for evaluating meat quality: Methods and techniques. Compr. Rev. Food Sci. Food Saf., 14(5): 523-535.

4. Yang, Y., Liang, G., Niu, G., Zhang, Y., Zhou, R., Wang, Y., $\mathrm{Mu}$, Y., Tang, Z. and Li, K. (2017) Comparative analysis of DNA methylome and transcriptome of skeletal muscle in lean-, obese-, and mini-type pigs. Sci. Rep., 7: 39883.

5. Hou, X., Mu, Y., Yang, Y., Li, K., Tang, Z. and Zhou, R. (2016) Genome-wide analysis of DNA methylation in obese, lean and miniature pig breeds. Sci. Rep., 6: 30160

6. Hausman, G.J., Basu, U., Du, M., Fernyhough-Culver, M. and Dodson, M.V. (2014) Intermuscular and intramuscular adipose tissues: Bad vs. Good adipose tissues. Adipocyte, 3(4): 242-255.

7. Bang, W.Y., Kim, S.W., Kwon, S.G., Hwang, J.H., Kim, T.W., Ko, M.S., Cho, I.C., Joo, Y.K., Cho, K.K., Jeong, J.Y. and Kim, C.W. (2013) Swine liver methylomes of Berkshire, Duroc and Landrace breeds by MeDIPS. Anim. Genet., 44(4): 463-466.

8. Ren, Z., Wang, Y., Ren, Y., Zhang, Z., Gu, W., Wu, Z., Chen, L., Mou, L., Li, R., Yang, H. and Dai, Y. (2017) Enhancement of porcine intramuscular fat content by overexpression of the cytosolic form of phosphoenolpyruvate carboxykinase in skeletal muscle. Sci. Rep., 7: 43746.

9. Marsman, J. and Horsfield, J.A. (2012) Long distance relationships: Enhancer-promoter communication and dynamic gene transcription. Biochim. Biophys. Acta, 1819(11-12): 1217-1227.

10. Hinkle, E.R., Wiedner, H.J., Black, A.J. and Giudice, J. (2019) RNA processing in skeletal muscle biology and disease. Transcription, 10(1): 1-20.

11. Weber, M., Davies, J.J., Wittig, D., Oakeley, E.J., Haase, M., Lam, W.L. and Schübeler, D. (2005) Chromosome-wide and promoter-specific analyses identify sites of differential DNA methylation in normal and transformed human cells. Nat. Genet., 37(8): 853-862.

12. Down, T.A., Rakyan, V.K., Turner, D.J., Flicek, P., Li, H., Kulesha, E., Gräf, S., Johnson, N., Herrero, J., Tomazou, E.M., Thorne, N.P., Bäckdahl, L., Herberth, M., Howe, K.L., Jackson, D.K., Miretti, M.M., Marioni, J.C., Birney, E., Hubbard, T.J.P., Durbin, R., Tavaré, S. and Beck, S. (2008) A bayesian deconvolution strategy for immunoprecipitation-based DNA methylome analysis. Nat. Biotechnol., 26(7): 779-785.

13. Wang, H., Wang, J., Ning, C., Zheng, X., Fu, J., Wang, A., Zhang, Q. and Liu, J.F. (2017) Genome-wide DNA methylation and transcriptome analyses reveal genes involved in immune responses of pig peripheral blood mononuclear cells to poly I: C. Sci. Rep., 7: 9709.

14. Titus, A.J., Gallimore, R.M., Salas, L.A. and Christensen, B.C. (2017) Cell-type deconvolution from DNA methylation: A review of recent applications. Hum. Mol. Genet., 26(R2): R216-R224.

15. Varley, K.E., Gertz, J., Bowling, K.M., Parker, S.L., Reddy, T.E., Pauli-Behn, F., Cross, M.K., Williams, B.A., Stamatoyannopoulos, J.A., Crawford, G.E., Absher, D.M., Wold, B.J. and Myers, R.M. (2013) Dynamic DNA methylation across diverse human cell lines and tissues. Genome Res., 23(3): 555-567.

16. Yang, Y., Fear, J., Hu, J., Haecker, I., Zhou, L., Renne, R., Bloom, D. and McIntyre, L.M. (2014) Leveraging biological replicates to improve analysis in chip-seq experiments. Comput. Struct. Biotechnol. J., 9(13): 1-10.

17. Schurch, N.J., Schofield, P., Gierliński, M., Cole, C., Sherstnev, A., Singh, V., Wrobel, N., Gharbi, K., Simpson, G.G., Owen-Hughes, T., Blaxter, M. and Barton, G.J. (2016) How many biological replicates are needed in an RNA-seq experiment and which differential expression tool should you use? RNA, 22(6): 839-851.

18. Palstra, R.J., Visser, M. and Kayser, M. (2012) HERC2 rs 12913832 modulates human pigmentation by attenuating chromatin-loop formation between a long-range enhancer and the OCA2 promoter. Genome Res., 22(3): 446-455.

19. Sanyal, A., Lajoie, B.R., Jain, G. and Dekker, J. (2012) The long-range interaction landscape of gene promoters. Nature, 489(7414): 109-113.

20. Grossman, S.R., Lander, E.S., Ray, J.P., Nguyen, T.H., Hacohen, N. and Engreitz, J. (2018) Positional specificity of different transcription factor classes within enhancers. Proc. Natl. Acad. Sci. USA., 115(30): E7222-E7230.

21. Chokeshaiusaha, K., Puthier, D., Nguyen, C. and 
Sananmuang, T. (2018) A demonstration of the H3 trimethylation ChIP-seq analysis of galline follicular mesenchymal cells and male germ cells. Asian Australas. J. Anim. Sci., 31(6): 791-797.

22. Langmead, B. and Salzberg, S.L. (2012) Fast gapped-read alignment with bowtie 2. Nat. Methods, 9(4): 357-9.

23. Li, H., Handsaker, B., Wysoker, A., Fennell, T., Ruan, J., Homer, N., Marth, G., Abecasis, G. and Durbin, R. (2009) The sequence alignment/map format and SAMtools. Bioinformatics, 25(16): 2078-2079.

24. Chokeshaiusaha, K., Thanawongnuwech, R., Puthier, D. and Nguyen, C. (2016) Inspection of C-type lectin superfamily expression profile in chicken and mouse dendritic cells. Thai J. Vet. Med., 46(3): 443-453.

25. Herwig, R., Morkel, M., Lienhard, M., Grimm, C. and Chavez, L. (2013) MEDIPS: Genome-wide differential coverage analysis of sequencing data derived from DNA enrichment experiments. Bioinformatics, 30(2): 284-286.

26. Hu, Y., Yan, C., Hsu, C.H., Chen, Q.R., Niu, K., Komatsoulis, G.A. and Meerzaman, D. (2014) Omiccircos: A simple-to-use R package for the circular visualization of multidimensional Omics data. Cancer Inform., 13: 13-20.

27. Gel, B. and Serra, E. (2017) KaryoploteR: An R/bioconductor package to plot customizable genomes displaying arbitrary data. Bioinformatics, 33(19): 3088-3090.

28. Murton, A.J., Marimuthu, K., Mallinson, J.E., Selby, A.L., Smith, K., Rennie, M.J. and Greenhaff, P.L. (2015) Obesity appears to be associated with altered muscle protein synthetic and breakdown responses to increased nutrient delivery in older men, but not reduced muscle mass or contractile function. Diabetes, 64(9): 3160-3171.

29. Yamauchi, J., Sekiguchi, M., Shirai, T., Yamada, M. and Ishimi, Y. (2013) Role of nuclear localization of PSMB1 in transcriptional activation. Biosci. Biotechnol. Biochem., 77(8): 1785-1787.

30. Müller-Höcker, J. (1990) Cytochrome C oxidase deficient fibres in the limb muscle and diaphragm of man without muscular disease: An age-related alteration. J. Neurol. Sci., 100(1-2): 14-21.

31. Hocquette, J.F., Cassar-Malek, I., Jurie, C., Bauchart, D., Picard, B. and Renand, G. (2012) Relationships between muscle growth potential, intramuscular fat content and different indicators of muscle fibre types in young Charolais bulls. Anim. Sci. J., 83(11): 750-758.

32. Berdeaux, R. and Stewart, R. (2012) cAMP signaling in skeletal muscle adaptation: Hypertrophy, metabolism, and regeneration. Am. J. Physiol. Metab., 303(1): E1-E17.

33. Londhe, P. and Guttridge, D.C. (2015) Inflammation induced loss of skeletal muscle. Bone, 80: 131-142.

34. Rheinheimer, J., de Souza, B.M., Cardoso, N.S., Bauer, A.C. and Crispim, D. (2017) Current role of the NLRP3 inflammasome on obesity and insulin resistance: A systematic review. Metabolism, 74: 1-9.

35. Summermatter, S., Marcelino, H., Arsenijevic, D., Buchala, A., Aprikian, O., Seydoux, J., Montani, J., Solinas, G. and Dulloo, A.G. (2009) Adipose tissue plasticity during catch-up fat driven by thrifty metabolism: Relevance for muscle-adipose glucose redistribution during catch-up growth. Diabetes, 58(10): 2228-2237.

36. Puolanne, E. and Immonen, K. (2014) Glycogen, in Encyclopedia of Meat Sciences. Academic Press, United States. p346-352.

37. Underwood, K.R., Means, W.J., Zhu, M.J., Ford, S.P., Hess, B.W. and Du, M. (2008) AMP-activated protein kinase is negatively associated with intramuscular fat content in longissimus dorsi muscle of beef cattle. Meat Sci., 79(2): 394-402.

38. Hohenauer, T. and Moore, A.W. (2012) The Prdm family: Expanding roles in stem cells and development. Development, 139(13): 2267-2282.

39. Hellsten, Y., Svensson, M., Sjödin, B., Smith, S., Christensen, A., Richter, E.A. and Bangsbo, J. (2001)
Allantoin formation and urate and glutathione exchange in human muscle during submaximal exercise. Free Radic. Biol. Med., 31(11): 1313-1322.

40. Kand'ár, R., Žáková, P. and Mužáková, V. (2006) Monitoring of antioxidant properties of uric acid in humans for a consideration measuring of levels of allantoin in plasma by liquid chromatography. Clin. Chim. Acta, 365(1-2): 249-256.

41. Sabio, G. and Davis, R.J. (2010) CJun NH2-terminal kinase 1 (JNK1): Roles in metabolic regulation of insulin resistance. Trends Biochem. Sci., 35(9): 490-496.

42. Fujii, N., Boppart, M.D., Dufresne, S.D., Crowley, P.F., Jozsi, A.C., Sakamoto, K., Yu, H., Aschenbach, W.G., Kim, S., Miyazaki, H., Rui, L., White, M.F., Hirshman, M.F. and Goodyear, L.J. (2004) Overexpression or ablation of JNK in skeletal muscle has no effect on glycogen synthase activity. Am. J. Physiol. Cell Physiol., 287(1): C200-C208.

43. Shen, Y., Luche, R., Wei, B., Gordon, M.L., Diltz, C.D. and Tonks, N.K. (2001) Activation of the JNK signaling pathway by a dual-specificity phosphatase, JSP-1. Proc. Natl. Acad. Sci. USA, 98(24): 13613-13618.

44. Xie, S.J., Li, J.H., Chen, H.F., Tan, Y.Y., Liu, S.R., Zhang, Y., Xu, H., Yang, J.H., Liu, S., Zheng, L.L., Huang, M.B., Guo, Y.H., Zhang, Q., Zhou, H. and Qu, L.H. (2018) Inhibition of the JNK/MAPK signaling pathway by myogenesis-associated miRNAs is required for skeletal muscle development. Cell Death Differ., 25(9): 1581-1597.

45. Sekine, Y., Tsuji, S., Ikeda, O., Sato, N., Aoki, N., Aoyama, K., Sugiyama, K. and Matsuda, T. (2006) Regulation of STAT3-mediated signaling by LMW-DSP2. Oncogene, 25(42): 5801-5806.

46. Moleres, A., Campión, J., Milagro, F.I., Marcos, A., Campoy, C., Garagorri, J.M., Gómez-Martínez, S., Martínez, J.A., Azcona-Sanjulián, M.C. and Martí, A. (2013) Differential DNA methylation patterns between high and low responders to a weight loss intervention in overweight or obese adolescents: The EVASYON study. FASEB $J ., 27(6):$ 2504-2512.

47. Keller, M., Hopp, L., Liu, X., Wohland, T., Rohde, K., Cancello, R., Klös, M., Bacos, K., Kern, M., Eichelmann, F., Dietrich, A., Schön, M.R., Gärtner, D., Lohmann, T., Dreßler, M., Stumvoll, M., Kovacs, P., DiBlasio, A.M., Ling, C., Binder, H., Blüher, M. and Böttcher, Y. (2017) Genome-wide DNA promoter methylation and transcriptome analysis in human adipose tissue unravels novel candidate genes for obesity. Mol. Metab., 6(1): 86-100.

48. Yang, Y., Li, W., Hoque, M., Hou, L., Shen, S., Tian, B. and Dynlacht, B.D. (2016) PAF complex plays novel subunit-specific roles in alternative cleavage and polyadenylation. PLoS Genet., 12(1): e1005794.

49. Mailloux, R.J., Xuan, J.Y., McBride, S., Maharsy, W., Thorn, S., Holterman, C.E., Kennedy, C.R.J., Rippstein, P., DeKemp, R., Da Silva, J., Nemer, M., Lou, M. and Harper, M.E. (2014) Glutaredoxin-2 is required to control oxidative phosphorylation in cardiac muscle by mediating deglutathionylation reactions. J. Biol. Chem., 289(21): 14812-14828.

50. Pisano, A., Cerbelli, B., Perli, E., Pelullo, M., Bargelli, V., Preziuso, C., Mancini, M., He, L., Bates, M.G., Lucena, J.R., Monica, P.L.D., Familiari, G., Petrozza, V., Nediani, C., Taylor, R.W., D'Amati, G. and Giordano, C. (2016) Impaired mitochondrial biogenesis is a common feature to myocardial hypertrophy and end-stage ischemic heart failure. Cardiovasc. Pathol., 25(2): 103-112.

51. Meneton, P., Schultheis, P.J., Greeb, J., Nieman, M.L., Liu, L.H., Clarke, L.L., Duffy, J.J., Doetschman, T., Lorenz, J.N. and Shull, G.E. (1998) Increased sensitivity to $\mathrm{K}+$ deprivation in colonic $\mathrm{H}, \mathrm{K}-\mathrm{ATPase}$-deficient mice. J. Clin. Invest., 101(3): 536-542.

52. Grifoni, E., Fabbri, A., Ciuti, G., Cerinic, M.M. and Pignone, A.M. (2014) Hypokalemia-induced rhabdomyolysis. Intern. Emerg. Med., 9(4): 487-488.

53. Zheng, S.L., Li, Z.Y., Song, J., Liu, J.M. and Miao, C.Y. 
(2016) Metrnl: A secreted protein with new emerging functions. Acta Pharmacol. Sin., 37(5): 571-579.

54. Güller, I. and Russell, A.P. (2010) MicroRNAs in skeletal muscle: Their role and regulation in development, disease and function. J. Physiol., 588(21): 4075-4087.

55. Perestenko, P.V., Pooler, A.M., Noorbakhshnia, M., Gray, A., Bauccio, C. and McIlhinney, R.A.J. (2010) Copines-1, -2, -3, -6 and -7 show different calcium-dependent intracellular membrane translocation and targeting. FEBS J., 277(24): 5174-5189.

56. Purandare, N., Somayajulu, M., Hüttemann, M., Grossman, L.I. and Aras, S. (2018) The cellular stress proteins CHCHD10 and MNRR1 (CHCHD2): Partners in mitochondrial and nuclear function and dysfunction. J. Biol. Chem., 293(17): 6517-6529.

57. Malynn, B.A., De Alboran, I.M., O'Hagan, R.C., Bronson, R., Davidson, L., DePinho, R.A. and Alt, F.W. (2000) N-myc can functionally replace c-myc in murine development, cellular growth, and differentiation. Genes Dev., 14(11): 1390-1399.

58. Velleman, S.G., Sporer, K.R.B., Ernst, C.W., Reed, K.M. and Strasburg, G.M. (2012) Versican, matrix Gla protein, and death-associated protein expression affect muscle satellite cell proliferation and differentiation. Poult. Sci., 91(8): 1964-1973.

59. Testoni, G., Duran, J., García-Rocha, M., Vilaplana, F., Serrano, A.L., Sebastián, D., López-Soldado, I., Sullivan, M.A., Slebe, F., Vilaseca, M., Muñoz-Cánoves, P. and Guinovart, J.J. (2017) Lack of glycogenin causes glycogen accumulation and muscle function impairment. Cell
Metab., 26(1): 256-266.e4.

60. Li, S., Zhang, J., Huang, S. and He, X. (2018) Genome-wide analysis reveals that exon methylation facilitates its selective usage in the human transcriptome. Brief. Bioinform., 19(5): 754-764.

61. Gallegos, J.E. and Rose, A.B. (2017) Intron DNA sequences can be more important than the proximal promoter in determining the site of transcript initiation. Plant Cell, 29(4): 843-853.

62. Shaul, O. (2017) How introns enhance gene expression. Int. J. Biochem. Cell Biol., 91(B): 145-155.

63. Li, M., Tian, S., Jin, L., Zhou, G., Li, Y., Zhang, Y., Wang, T., Yeung, C.K.L., Chen, L., Ma, J., Zhang, J., Jiang, A., Li, J., Zhou, C., Zhang, J., Liu, Y., Sun, X., Zhao, H., Niu, Z., Lou, P., Xian, L., Shen, X., Liu, S., Zhang, S., Zhang, M., Zhu, L., Shuai, S., Bai, L., Tang, G., Liu, H., Jiang, Y., Mai, M., Xiao, J., Wang, X., Zhou, Q., Wang, Z., Stothard, P., Xue, M., Gao, X., Luo, Z., Gu, Y., Zhu, H., Hu, X., Zhao, Y., Plastow, G.S., Wang, J., Jiang, Z., Li, K., Li, N., Li, X. and Li, R. (2013) Genomic analyses identify distinct patterns of selection in domesticated pigs and Tibetan wild boars. Nat. Genet., 45(12): 1431-1438.

64. Moore, L.D., Le, T. and Fan, G. (2013) DNA methylation and its basic function. Neuropsychopharmacology, 38(1): 23-38.

65. Turatsinze, J.V., Thomas-Chollier, M., Defrance, M. and van Helden, J. (2008) Using RSAT to scan genome sequences for transcription factor binding sites and cis-regulatory modules. Nat. Protoc., 3(10): 1578-1588.

$* * * * * * * *$ 